\title{
Sistem Pakar Diagnosa Penyakit Kulit Pada Anjing Ras Dengan Metode Teorema Bayes
}

\section{Expert System for Diagnosting Dog Skin Diseases Using Bayes Method}

\author{
Paulus Hendi Kristyanto ${ }^{1}$, Ozzi Suria ${ }^{2}$ \\ ${ }^{1,2}$ Program Studi Sistem Informasi, Fakultas Teknologi Informasi, Universitas Mercu Buana Yogyakarta \\ J1. Wates Km. 10 Yogyakarta, 55753, Indonesia \\ Email: hendi.paulus@gmail.com¹, ozzisuria@mercubuana-yogya.ac.id²
}

\begin{abstract}
ABSTRAK
Penyakit kulit merupakan kasus yang paling sering muncul pada kasus penyakit anjing ras. Perbedaan iklim serta keadaan lingkungan dari habibat asli menjadikan anjing ras rentan terserang penyakit kulit. Pengetahuan masyarakat yang masih minim mengenai penyakit kulit pada anjing ras dan ketersediaan jumlah dokter hewan yang masih sangat sedikit menjadikan banyak kasus penyakit kulit pada anjing ras tidak tertangani dengan baik. Dari permasalahan tersebut, penelitian ini mencoba untuk membuat sebuah sistem pakar yang dapat membantu diagnosa penyakit kulit pada anjing ras. Data yang digunakan dalam pembuatan sistem pakar ini diperoleh dari literatur dan data rekam medis pada klinik "Graha Pet Care". Diagnosa dilakukan dengan cara menginputkan gejala-gejala yang muncul pada anjing. Kemudian, sistem akan melakukan penghitungan nilai setiap bobot terkait dengan 8 jenis penyakit yang dipakai dengan metode teorema bayes. Hasil nilai bayes tertinggi akan dipilih sebagai diagnosa sistem. Berdasarkan 11 data rekam medis yang digunakan sebagai data uji pada sistem pakar diagnosa penyakit kulit pada anjing ras dengan metode teorema bayes ini, didapatkan 10 kesesuaian diagnosa dan 1 kasus tidak sesuai dengan diagnosa dokter. Dengan demikian dapat disimpulkan bahwa dari 11 data uji sampel yang digunakan dalam penelitian ini, sistem pakar diagnosa penyakit kulit pada anjing ras dengan metode Teorema Bayes ini dapat memberikan hasil diagnosa dengan akurasi sebesar $91 \%$.
\end{abstract}

Kata kunci: Diagnosa; Sistem Pakar; Teorema Bayes

\section{ABSTRACT}

Skin diseases are the most common cases on dogs. Climate differences and environmental conditions could become factors that may make dog susceptible to skin diseases. The deficiancy of public knowledge about skin diseases in dogs, as well as the small number of veterinary providers, make most cases of skin diseases in dogs not handled properly. Based on this problem, this research tries to create expert system to help diagnosing skin diseases on dogs. This research uses data from literatures and medical records from "Graha Pet Care" clinic. The diagnosis is done by inputing the skin disease symptoms to the system. The system will perform the calculation of the values which were associated with the 8 types of diseases used by Bayes Theorem method. The highest bayes value results will be selected as the diagnosis result. Based on 11 medical records that used as experimental data, 10 matches diagnostic were obtained and 1 case was unmatched with doctor's diagnosis. Thus, it can be concluded that based on the 11 experimental sample data, the expert system with Bayes Theorem method can provide diagnosis result with accuracy about $91 \%$.

Keywords: Bayes Theorem; Diagnosis; Expert System

\section{PENDAHULUAN}

Anjing Ras (Dog Breed) adalah kelompok-kelompok anjing peliharaan yang berkerabat dekat dan memiliki penampilan yang sama. Semuanya berasal dari satu spesies, yakni canis lupus familiaris. Anjing ras dikembang biakan oleh manusia dengan bibit dasar yang diketahui dan memenuhi standar satu ras anjing (Subronto, 2006). Saat ini anjing ras merupakan 
hewan peliharaan yang cukup banyak diminati masyarakat. Kelucuan serta kecerdasannya menjadi salah satu alasan untuk memelihara hewan tersebut menjadi hewan peliharaan sekaligus penjaga rumah yang hebat. Harganya yang cukup mahal juga menjadikan berternak anjing ras menjadi salah satu bisnis yang cukup menggiurkan.

Penyakit kulit adalah keadaan dimana kulit mengalami gangguan (abnormal) yang dapat disebabkan oleh virus, bakteri, dan infeksi (Subronto, 2006). Penyakit kulit pada anjing ras merupakan salah satu penyakit yang paling umum, kondisi lingkungan serta iklim yang berbeda dari habitat aslinya merupakan salah satu penyebab anjing ras sangat rentan terserang penyakit kulit. Pada dasarnya semua penyakit kulit tidak berbahaya dan mudah disembuhkan jika mendapatkan penanganan yang tepat (Siligipoe, 2013). Walaupun penyakit kulit berbeda dengan rabies dan penyakit berbahaya lainya, namun penyakit kulit juga merupakan salah satu hal yang sangat mengganggu, dikarenakan anggapan pemilik anjing perihal nilai lebih pada anjing ras adalah penampilanya. Kebiasaanya berinteraksi dengan manusia juga merupakan hal yang sangat mengganggu bagi pemilik anjing yang anjingnya terkena penyakit kulit. Banyak pemilik anjing takut jika penyakit kulit tersebut menular kepada sang pemilik. Walaupun ada beberapa penyakit kulit anjing dan manusia yang mempunyai kemiripan nama, akan tetapi penyakit kulit pada anjing mempunyai karakteristik yang berbeda (Soeharsono, 2007). Jenis kulit pada anjing cenderung sangat berbeda dengan jenis kulit pada manusia.

Permasalahan yang dihadapi di Indonesia adalah terkait pengetahuan masyarakat yang masih sangat minim perihal penyakit kulit anjing ras. Pengetahuan masyarakat yang minim serta ketersediaan dokter hewan kecil yang sangat terbatas menjadikan banyak kasus penyakit anjing tersebut yang tidak tertangani dengan baik. Berdasarkan permasalahan tersebut, peneliti melakukan penelitian dengan judul sistem pakar diagnosa penyakit kulit pada anjing ras dengan metode teorema bayes. Adapun proses perancangan sistem pakar diagnosa penyakit kulit pada anjing ras dengan metode teorema bayes ini adalah dengan melibatkan pakar, yaitu dokter hewan. Datadata yang didapatkan dari pakar berupa data jenis penyakit, data gejala penyakit, nilai pembobotan setiap gejala, dan data rekam medis sebagai data bahan uji aplikasi. Proses penentuan diagnosa adalah dengan melakukan perhitungan nilai probabilitas gejala dari masing-masing jenis penyakit kulit pada anjing ras menggunakan teorema bayes. Hasil dari penelitian ini diharapkan dapat memberi manfaat bagi pengguna untuk dapat melakukan diagnosa dini terhadap anjing ras yang terserang penyakit dan bagaimana tata cara penangananya.

\section{TINJAUAN PUSTAKA}

(Noviyanti, Suheri, \& Midyanti, 2017) "Sistem Pakar Untuk Diagnosa Penyakit Rabies Pada Anjing Menggunakan Metode Fuzzy Mamdani Berbasis WEB". Rabies merupakan penyakit menular yang disebabkan oleh virus dari Genus Lyssavirus Famili Rhabdovirus.Anjing merupakan salah satu hewan yang paling rentan terserang virus rabies. Menurut laporanDinas Peternakan dan Kesehatan Hewan Provinsi Kalimantan Barat, sekitar $90 \%$ virus rabies ditularkan oleh anjing pada manusia dan kasus kematian yang disebabkan oleh gigitan anjing telah terjadi di beberapa daerah. Anjing merupakan hewan yang sering berinteraksi langsung dengan manusia. Pemilik anjing terkadang tidak mengetahui apakah anjing yang dipelihara terbebas dari penyakit rabies. Oleh karena hal tersebut, dibutuhkan sebuah sistem yang dapat memberikan suatu diagnosa anjing penderita rabies. Sistem yang digunakan pada penelitian ini adalah sistem pakar dengan menggunakan metode Fuzzy Mamdani. Variabel masukan yang digunakan pada penelitian ini terdiri dari 4 variabel, yaitu variabel kelompok gejala 1, variabel kelompok gejala 2, variabel kelompok gejala 3, dan variabel kelompok gejala 4. Tiap variabel terdiri dari beberapa gejala dan tiap gejala memiliki nilai bobot. Gejala-gejala yang dipilih oleh user akan dikelompokkan berdasarkan kelompok gejala tiap variabel. Tiap variabel akan memiliki total bobot gejala. Total bobot gejala tersebut yang akan dikonversi untuk melakukan proses diagnosa menggunakan metode Fuzzy Mamdani. Output pada penelitian ini berupa tingkat (fase) penyakit rabies pada anjing, yaitu bukan rabies, rabies inkubasi, rabies ganas, rabies diam, dan rabies kelumpuhan. Akurasi keberhasilan yang diperoleh pada penelitian ini berdasarkan 50 data uji adalah sebesar $86 \%$

(Rohajawati, 2010) "Sistem Pakar Diagnosa Penyakit Unggas Dengan Metode 
Certainty Factor". Untuk peningkatan produktivitas serta area manajerial yang dapat mengambil kesimpulan dengan cepat. Begitupula dengan organisasi yang melakukan bisnis peternakan, yang sangat menjanjikan, namun perlu kewaspadaan yang tinggi terhadap berbagai jenis penyakit yang disebabkan virus ataupun bakteri. Manfaat yang diperoleh dari sistem pakar yang mampu melakukan diagnosis dengan cepat terhadap gejala penyakit yang ditimbulkan diharapkan mampu membantu para peternak dalam mengantisipasi kerugian yang diakibatkan serangan penyakit. Diperlukan keakuratan dan ketepatan penghitungan dalam mendiagnosis gejala penyakit guna menyimpulkan hasil dengan menggunakan metode Certainty Factors. Berdasarkan 100 data uji sampel yang digunakan dalam penelitian ini, sistem pakar dapat mendiagnosa dengan keakuratan sebersar $85 \%$.

(Ningrum, Anra, \& Nasution, 2016) "Sistem Pakar Diagnosa Penyakit Menular Pada Anjing Menggunakan Metode Dempster". Anjing merupakan salah satu hewan yang dapat diajak bermain, tinggal bersama manusia dan diajak bersosialisasi dengan manusia. Apabila anjing tidak dirawat dengan baik, maka akan berdampak buruk bagi kondisi kesehatan anjing dan dapat terserang penyakit menular sehingga dapat menyebabkan kematian, baik terhadap anjing yang menularkan maupun yang ditularkan. Dibutuhkan suatu alternatif untuk mengatasi hal tersebut yang dapat memberikan kemudahan kepada pemilik anjing untuk dapat mengetahui penyakit menular yang diderita oleh anjing peliharaannya. Salah satu alternatif tersebut adalah sistem pakar. Sistem pakar merupakan sistem yang berusaha mengadopsi pengetahuan manusia ke komputer yang dirancang untukmenyelesaikan masalah seperti layaknya seorang pakar. Penelitian ini bertujuan untuk mendiagnosa penyakitmenular pada anjing dengan menerapkan metode Dempster Shafer. Nilai kepercayaan (belief) pada metode Dempster Shafer yang didapat dari probabilitas kemunculan setiap gejala terhadap masingmasing penyakit pada data sampel kasus akan digunakan dalam proses perhitungan untuk mendapatkan hasil berupa persentase penyakit menular yang diderita oleh anjing. Hasil keluaran dari sistem ini adalah jenis penyakit yang dialami dan informasi mengenai jenis penyakit yang dialami. Berdasarkan pengujian terhadap 30 data kasus didapat bahwa sistem dapat mendiagnosa penyakit menular pada anjing dengan tingkat keakuratan sebesar $100 \%$ berdasarkan 45 data sampel kasus yang digunakan dalam menentukan nilai beliefpada metodeDempster Shafer

(Harijanto \& Latif, 2017). "Sistem Pakar Diagnosa Penyakit Pada Kucing Dengan Metode Teorema Bayes Berbasis Android". Kucing sebagai hewan periharaan yang digemarin oleh masyarakat Indonesia namun tidak diimbangi dengan tersedianya dokter hewan yang mencukupi, pada penelitiannya diharapkan dapat menjadi alternatif bantuan pada pemilik kucing dalam memperoleh informasi penyakit pada kucing dan sekaligus dapat mengetahui pemecahan masalah atau solusi yang tepat untuk menangani penyakit tersebut. Data yang diperoleh dari studi literature dari para ahli selanjutnya akan menentukan data penyakit dan data gejala penyakit. Dalam tahap ini, terdapat dua langkah yang dilakukan yaitu proses data identifikasi penyakit dan proses data indentifikasi gejala gejala yang menghasilkan nilai probabilitas sebesar 90\%, sehingga dapat disimpulkan bahwa dengan menggunakan data yang dihasilkan dari uji coba aplikasi dapat berjalan baik secara fungsional untuk mendiagnosa penyakit pada kucing menggunakan metode Teorema bayes, yang dapat memberikan kepastian kepada user akan jenis penyakit dan solusi yang diberikan oleh sistem dan aplikasi ini di rancang menggunakan platform berbasis Android dan database MySQL.

(Larasati \& Arief, 2016) "Sistem Pakar Diagnosa Awal Penyakit Pada Kucing Berbasis WEB Dengan Metode Certainly Factor". Membangun sistem pakar yang berusaha mengadopsi pengetahuan manusia ke dalam komputer agar dapat menyelesaikan masalah seperti yang biasa dilakukan oleh pakar. Penelitian ini bertujuan untuk mengimplementasikan metode certainty factor pada sistem diagnosa penyakit kulit pada kucing. Metode certainty factor merupakan suatu metode untuk membuktikan apakah suatu fakta itu pasti ataukah tidak pasti. Metode ini memberikan ruang pada pakar dalam memberikan nilai keyakinan pada pengetahuan yang diungkapkannya. Hasil penelitian menunjukkan bahwa certainty factor dapat digunakan sebagai cara untuk mengatasi ketidakpastian untuk diagnosa awal penyakit kulit pada kucing. Hasilnya sistem pakar untuk mendiagnosa penyakit pada kucing ini 
mempunyai tingkat akurasi sebersar $90 \%$ dari 20 kasus data uji sampel yang digunakan.

\section{METODOLOGI PENELITIAN \\ 3.1 Alur Penelitian}

Alur penelitian perancangan sistem pakar diagnosa penyakit kuulit pada anjing ras dengan metode teorema bayesdigambarkan pada gambar 3.1.

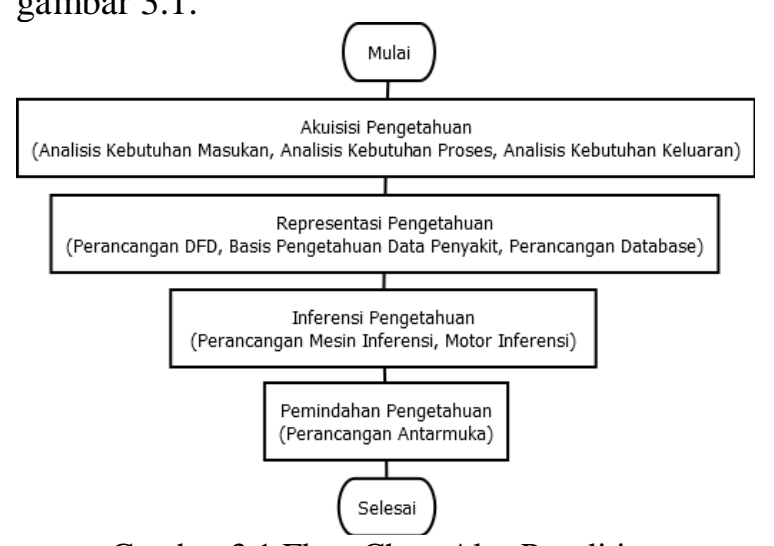

\subsection{Perancangan DFD}

DFD (Data Flow Diagram) sistem pakar diagnosa penyakit kuulit pada anjing ras dengan metode teorema bayes digambarkan pada Gambar 3.2 berikut.

\subsection{Perancangan ERD}

ERD (Entity Relationship Diagram) perancangan sistem pakar diagnosa penyakit kulit pada anjing ras dengan metode teorema bayes digambarkan pada gambar 3.3 berikut.

Gambar 3.1 Flow Chart Alur Penelitian

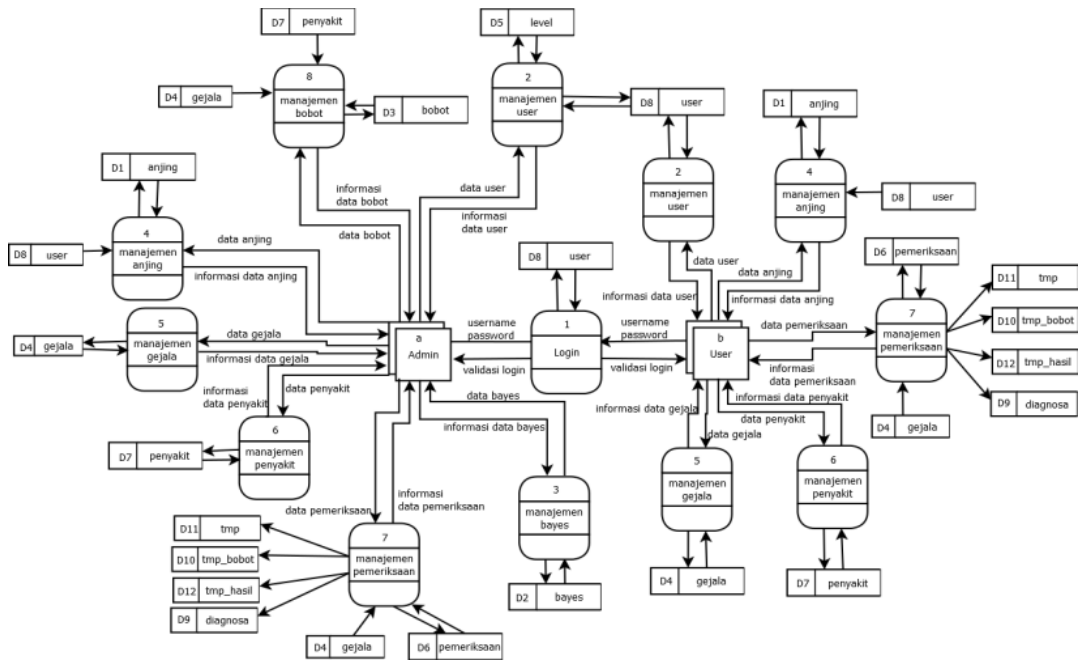

Gambar 3.2 DFD (Data Flow Diagram)

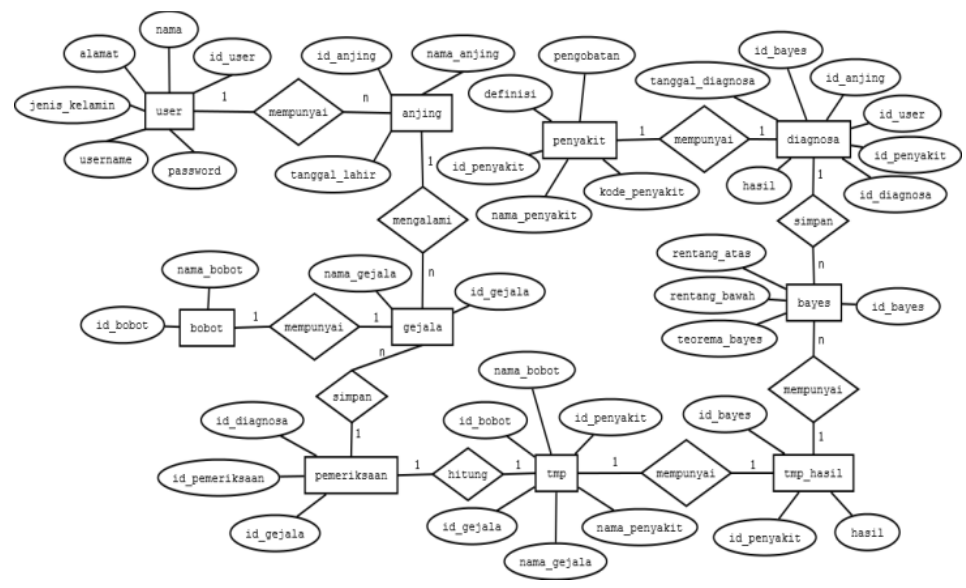

Gambar 3.3 ERD (Entity Relationship Diagram) 


\subsection{Motor Inferensi}

Motor Inferensisistem pakar diagnosa penyakit kuulit pada anjing ras dengan metode teorema bayes digambarkan pada Gambar 3.4berikut

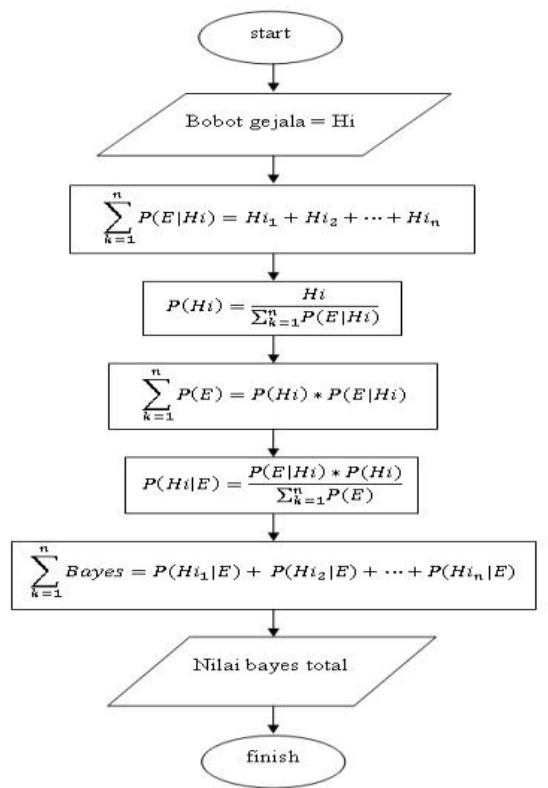

Gambar 3.4. Flow Chart Motor Inferensi

Keterangan:

$P(H i \mid E)$ : Probabilitas hipotesa Hi terjadi jika evidence E terjadi.

$P(E \mid H i)$ : Probabilitas munculnya evidence $\mathrm{E}$ jika diketahui hipotesa Hk benar.

$P(H i) \quad$ : Probabilitas hipotesa Hk, tanpa memandang evidence apapun.

$n \quad$ : Jumlah hipotesa yang mungkin

\section{PEMBAHASAN}

\subsection{Data Penyakit}

Data penyakit dan gejala didapatkan melalui uji kepustakaan dan proses wawancara dengan pakar

Tabel 4.1 Data Penyakit dan Gejala

\begin{tabular}{|l|l|}
\hline Jenis Penyakit & \multicolumn{1}{c|}{ Gejala } \\
\hline Scabies & G01 Bulu rontok \\
\cline { 2 - 3 } & G02 Kulit berkerak \\
\cline { 2 - 3 } & G03 Bau busuk \\
\cline { 2 - 2 } & G04 Nafsu makan menurun \\
\cline { 2 - 3 } & G05 Berat badan menurun \\
\cline { 2 - 2 } & G06 Lesu \\
\hline Demodekosis & G01 Bulu rontok \\
\cline { 2 - 2 } & G07 Ruam kulit kemerahan \\
\cline { 2 - 2 } & G08 Conjungtiva hiperemis \\
\cline { 2 - 2 } & G09 Sering menggaruk badan \\
\cline { 2 - 2 } & G10 Kaki bengkak \\
\hline Dermatomicosis & G01 Bulu rontok \\
\cline { 2 - 2 } & G09 Sering menggaruk badan \\
\cline { 2 - 2 } & G08 Conjungtiva hiperemis \\
\cline { 2 - 2 } & G11 Ada ketombe \\
\cline { 2 - 2 } & G12 Ada parasite \\
\hline
\end{tabular}

\begin{tabular}{|l|l|}
\hline \multirow{4}{*}{ Dermatitis } & G01 Bulu rontok \\
\cline { 2 - 2 } & G07 Ruam kulit kemerahan \\
\cline { 2 - 2 } Impetigo & G13 Bintik-bintik tanpa nanah \\
\hline & G14 Bintik-bintik bernanah \\
\cline { 2 - 2 } Candidiasis & G03 Bau busuk \\
\cline { 2 - 2 } & G06 Lesu \\
\cline { 2 - 2 } & G15 Diare \\
\cline { 2 - 2 } & G01 Bulu rontok \\
\cline { 2 - 2 } & G16 Ruam kulit berwarna gelap \\
\cline { 2 - 2 } & G03 Bau busuk \\
\cline { 2 - 2 } & G02 Kulit berkerak \\
\hline Ranine Distemper & G01 Bulu rontok \\
\cline { 2 - 2 } & G02 Kulit berkerak \\
\cline { 2 - 2 } & G17 Demam \\
\cline { 2 - 2 } & G15 Diare \\
\cline { 2 - 2 } & G08 Conjungtiva hiperemis \\
\hline Ring Worm & G01 Bulu rontok \\
\cline { 2 - 2 } & G18 Kaki kapalan \\
\cline { 2 - 2 } & G19 Lesi (luka) berbentuk bulat \\
\cline { 2 - 2 } & G03 Bau busuk \\
\cline { 2 - 2 } & G20 Sering menjilati lesi (luka) \\
\hline
\end{tabular}

\subsection{Data Bobot}

Data bobot didapatkan melalui proses wawancara dengan pakar

Tabel 4.2 Data Bobot

\begin{tabular}{|c|c|c|}
\hline $\begin{array}{c}\text { Nama } \\
\text { Penyakit }\end{array}$ & Gejala & Bobot \\
\hline \multirow[t]{6}{*}{ Scabies } & Bulu rontok & 0,9 \\
\hline & Kulit berkerak & 0,9 \\
\hline & Bau Busuk & 0,6 \\
\hline & Nafsu makan menurun & 0,4 \\
\hline & Berat badan menurun & 0,4 \\
\hline & Lesu & 0,3 \\
\hline \multirow[t]{5}{*}{ Demodekosis } & Bulu rontok & 0,7 \\
\hline & Ruam kulit kemerahan & 0,9 \\
\hline & Conjungtiva hiperemis & 0,7 \\
\hline & Sering menggaruk badan & 0,5 \\
\hline & Kaki bengkak & 0,8 \\
\hline \multirow{5}{*}{$\begin{array}{l}\text { Dermato- } \\
\text { micosis }\end{array}$} & Bulu rontok & 0,6 \\
\hline & Sering menggaruk badan & 0,7 \\
\hline & Conjungtiva hiperemis & 0,5 \\
\hline & Ada ketombe & 0,6 \\
\hline & Ada parasit & 1 \\
\hline \multirow[t]{3}{*}{ Dermatitis } & Bulu rontok & 0,5 \\
\hline & Ruam kulit kemerahan & 0,7 \\
\hline & Bintik-bintik tanpa nanah & 1 \\
\hline \multirow[t]{4}{*}{ Impetigo } & Bintik-bintik bernanah & 1 \\
\hline & Bau busuk & 0,8 \\
\hline & Lesu & 0,5 \\
\hline & Diare & 0,5 \\
\hline \multirow[t]{4}{*}{ Candidiasis } & Bulu rontok & 0,7 \\
\hline & Ruam kulit berwarna gelap & 1 \\
\hline & Bau Busuk & 0,5 \\
\hline & Kulit berkerak & 0,7 \\
\hline \multirow{5}{*}{$\begin{array}{l}\text { Canine } \\
\text { Distemper }\end{array}$} & Bulu rontok & 0,5 \\
\hline & Kulit berkerak & 0,8 \\
\hline & Demam & 0,7 \\
\hline & Diare & 0,4 \\
\hline & Conjungtiva hiperemi & 0,3 \\
\hline \multirow[t]{2}{*}{ Ring Worm } & Bulu rontok & 0,4 \\
\hline & Kaki kapalan & 0,5 \\
\hline
\end{tabular}


\begin{tabular}{|l|l|} 
Lesi (luka) berbentuk bulat & 1 \\
\hline
\end{tabular}

\subsection{Rentang Aturan}

Nilai hasil dari proses penghitungan dengan metode teorema bayes nantinya akan dikategorikan sesuai dengan rentang nilai aturan bayes dari pakar. Rentang aturan bayes tersebut dirangkum seperti terlihat pada Tabel 4.3 berikut

Tabel 4. 3 Rentang Aturan Bayes

\begin{tabular}{|l|c|c|}
\hline \multicolumn{1}{|c|}{ Aturan } & $\begin{array}{c}\text { Rentang } \\
\text { Bawah }\end{array}$ & $\begin{array}{c}\text { Rentang } \\
\text { Atas }\end{array}$ \\
\hline Tidak Ada & 0 & 0.2 \\
\hline Mungkin & 0.3 & 0.4 \\
\hline Kemungkinan Besar & 0.5 & 0.6 \\
\hline Hampir Pasti & 0.7 & 0.8 \\
\hline Pasti & 0.9 & 1 \\
\hline
\end{tabular}

\subsection{Proses Inferensi}

\section{Scabies}

\begin{tabular}{|c|c|}
\hline \multicolumn{2}{|c|}{ Hitung Nilai Semesta } \\
\hline Gejala & Bobot \\
\hline Bulu rontok & 0.9 \\
\hline Kulit berkerak & 0.9 \\
\hline Bau busuk & 0.6 \\
\hline Nafsu makan menurun & 0.4 \\
\hline Berat badan menurun & 0.4 \\
\hline Lesu & 0.3 \\
\hline Total & 3.5 \\
\hline \multicolumn{2}{|c|}{ Hitung $P(H i)$} \\
\hline Gejala & Nilai Semesta $P(H i)$ \\
\hline Bulu rontok & $0.9 / 3.5=0.26$ \\
\hline Kulit berkerak & $0.9 / 3.5=0.26$ \\
\hline Bau busuk & $0.6 / 3.5=0.18$ \\
\hline Nafsu makan menurun & $0.4 / 3.5=0.12$ \\
\hline Berat badan menurun & $0.4 / 3.5=0.12$ \\
\hline Lesu & $0.3 / 3.5=0.09$ \\
\hline \multicolumn{2}{|c|}{ Probabilitas H Tanpa Memandang Nilai Apapun } \\
\hline Bulu rontok & $0.26 \times 0.9=0.24$ \\
\hline Kulit berkerak & $0.26 \times 0.9=0.24$ \\
\hline Bau busuk & $0.18 \times 0.6=0.11$ \\
\hline Nafsu makan menurun & $0.12 \times 0.4=0.05$ \\
\hline Berat badan menurun & $0.12 \times 0.4=0.05$ \\
\hline Lesu & $0.09 \times 0.3=0.03$ \\
\hline \multicolumn{2}{|c|}{$\sum P(H i) \times P(E \mid H i-n)=0.69$} \\
\hline \multicolumn{2}{|c|}{ Mencari nilai $P(H i \mid E)$} \\
\hline Bulu rontok & $0.9 \times 0.26 / 0.69=0.34$ \\
\hline Kulit berkerak & $0 \times 0 / 0.69=0$ \\
\hline Bau busuk & $0.6 \times 0.18 / 0.69=0.16$ \\
\hline Nafsu makan menurun & $0 \times 0 / 0.69=0$ \\
\hline Berat badan menurun & $0 \times 0 / 0.69=0$ \\
\hline Lesu & $0 \times 0 / 0.69=0$ \\
\hline
\end{tabular}

\section{Demodekosis}

\begin{tabular}{|l|c|}
\hline \multicolumn{2}{|c|}{ Hitung Nilai Semesta } \\
\hline \multicolumn{1}{|c|}{ Gejala } & Bobot \\
\hline Bulu rontok & 0.7 \\
\hline Ruam kulit kemerahan & 0.9 \\
\hline Conjungtiva hiperemi & 0.7 \\
\hline Sering menggaruk badan & 0.5 \\
\hline
\end{tabular}

Bau busuk

0,7

\subsection{Pengujian}

Proses pengujian sistem dilakukan dengan menyeleksi gejala dengan menggunakan data pemeriksaan anjing yang diperoleh. Data sampel yang digunakan mengambil salah satu sampel data kasus seperti yang dapat dilihat pada Tabel 4.4 berikut.

Tabel 4. 4 Data Sampel

\begin{tabular}{|l|l|c|}
\hline $\begin{array}{c}\text { Nama } \\
\text { Anjing }\end{array}$ & \multicolumn{1}{|c|}{ Gejala } & $\begin{array}{c}\text { Kode } \\
\text { Gejala }\end{array}$ \\
\hline \multirow{3}{*}{ Jodi } & Bulu rontok & G01 \\
\cline { 2 - 3 } & Kaki kapalan & G18 \\
\cline { 2 - 3 } & Bau busuk & G03 \\
\cline { 2 - 3 } & $\begin{array}{l}\text { Lesi (luka) berbentuk } \\
\text { bulat }\end{array}$ & G19 \\
\hline
\end{tabular}

\begin{tabular}{|c|c|}
\hline Kaki bengkak & 0.8 \\
\hline Total & 3.6 \\
\hline \multicolumn{2}{|c|}{ Hitung $P(H i)$} \\
\hline Gejala & Nilai Semesta $P(H i)$ \\
\hline Bulu rontok & $0.7 / 3.6=0.11$ \\
\hline Ruam kulit kemerahan & $0.9 / 3.6=0.25$ \\
\hline Conjungtiva hiperemi & $0.7 / 3.6=0.11$ \\
\hline Sering menggaruk badan & $0.5 / 3.6=0.14$ \\
\hline Kaki bengkak & $0.8 / 3.6=0.23$ \\
\hline \multicolumn{2}{|c|}{ Probabilitas H Tanpa Memandang Nilai Apapun } \\
\hline Bulu rontok & $0.11 \times 0.7=0.14$ \\
\hline Ruam kulit kemerahan & $0.25 \times 0.9=0.23$ \\
\hline Conjungtiva hiperemi & $0.11 \times 0.7=0.14$ \\
\hline Sering menggaruk badan & $0.14 \times 0.5=0.07$ \\
\hline Kaki bengkak & $0.23 \times 0.8=0.18$ \\
\hline \multicolumn{2}{|l|}{$\sum P(H i) \times P(E \mid H i-n)=0.75$} \\
\hline \multicolumn{2}{|c|}{ Mencari nilai $P(H i \mid E)$} \\
\hline Bulu rontok & $0.7 \times 0.11 / 0.75=0.19$ \\
\hline Ruam kulit kemerahan & $0 \times 0 / 0.75=0$ \\
\hline Conjungtiva hiperemi & $0 \times 0 / 0.75=0$ \\
\hline Sering menggaruk badan & $0 \times 0 / 0.75=0$ \\
\hline Kaki bengkak & $0 \times 0 / 0.75=0$ \\
\hline
\end{tabular}

\section{Dermatomicosis}

\begin{tabular}{|l|c|}
\hline \multicolumn{2}{|c|}{ Hitung Nilai Semesta } \\
\hline \multicolumn{1}{|c|}{ Gejala } & Bobot \\
\hline Bulu rontok & 0.6 \\
\hline Sering menggaruk badan & 0.7 \\
\hline Conjungtiva hiperemi & 0.5 \\
\hline Ada Ketombe & 0.6 \\
\hline Ada parasite & 1 \\
\hline Total & $\mathbf{3 . 4}$ \\
\hline \multicolumn{2}{|c|}{ Hitung $\boldsymbol{P}(\boldsymbol{H i})$} \\
\hline Gejala & Nilai Semesta $\boldsymbol{P}(\boldsymbol{H i})$ \\
\hline Bulu rontok & $0.6 / 3.4=0.18$ \\
\hline Sering menggaruk badan & $0.7 / 3.4=0.21$ \\
\hline Conjungtiva hiperemi & $0.5 / 3.4=0.15$ \\
\hline Ada Ketombe & $0.6 / 3.4=0.18$ \\
\hline Ada parasite & $1 / 3.4=0.30$ \\
\hline Probabilitas H Tanpa Memandang Nilai Apapun \\
\hline
\end{tabular}




\begin{tabular}{|l|l|}
\hline Bulu rontok & $0.18 \times 0.6=0.11$ \\
\hline Sering menggaruk badan & $0.21 \times 0.7=0.15$ \\
\hline Conjungtiva hiperemi & $0.15 \times 0.5=0.08$ \\
\hline Ada Ketombe & $0.18 \times 0.6=0.11$ \\
\hline Ada parasite & $0.30 \times 1=0.30$ \\
\hline$\sum \boldsymbol{P}(\boldsymbol{H} \boldsymbol{)}) \boldsymbol{x} \boldsymbol{P}(\boldsymbol{E} \mid \boldsymbol{H i}-\boldsymbol{n})=\mathbf{0 . 7 3}$ \\
\hline \multicolumn{2}{|c|}{ Mencari nilai $\boldsymbol{P}(\boldsymbol{H} \mid \boldsymbol{E})$} \\
\hline Bulu rontok & $0.6 \times 0.18 / 0.73=0.15$ \\
\hline Sering menggaruk badan & $0 \times 0 / 0.73=0$ \\
\hline Conjungtiva hiperemi & $0 \times 0 / 0.73=0$ \\
\hline Ada Ketombe & $0 \times 0 / 0.73=0$ \\
\hline Ada parasite & $0 \times 0 / 0.73=0$ \\
\hline$\sum \boldsymbol{P}(\boldsymbol{H} \mid \boldsymbol{E})=\mathbf{0 . 1 5}$ & \\
\hline
\end{tabular}

\section{Dermatitis}

\begin{tabular}{|c|c|}
\hline \multicolumn{2}{|c|}{ Hitung Nilai Semesta } \\
\hline Gejala & Bobot \\
\hline Bulu rontok & 0.5 \\
\hline Ruam kulit kemerahan & 0.7 \\
\hline Bintik bintik tanpa nanah & 1 \\
\hline Total & 2.2 \\
\hline \multicolumn{2}{|c|}{ Hitung $P(\mathbf{H i})$} \\
\hline Gejala & Nilai Semesta $P(H i)$ \\
\hline Bulu rontok & $0.5 / 2.2=0.23$ \\
\hline Ruam kulit kemerahan & $0.7 / 2.2=0.32$ \\
\hline Bintik bintik tanpa nanah & $1 / 2.2=0.46$ \\
\hline \multicolumn{2}{|c|}{ Probabilitas H Tanpa Memandang Nilai Apapun } \\
\hline Bulu rontok & $0.23 \times 0.5=0.12$ \\
\hline Ruam kulit kemerahan & $0.32 \times 0.7=0.23$ \\
\hline Bintik bintik tanpa nanah & $0.46 \times 1=0.46$ \\
\hline \multicolumn{2}{|l|}{$\sum P(H i) \times P(E \mid H i-n)=0.80$} \\
\hline \multicolumn{2}{|c|}{ Mencari nilai $P(H i \mid E)$} \\
\hline Bulu rontok & $0.5 \times 0.23 / 0.80=0.15$ \\
\hline Ruam kulit kemerahan & $0 \times 0 / 0.80=0$ \\
\hline Bintik bintik tanpa nanah & $0 \times 0 / 0.80=0$ \\
\hline$\sum P(H i \mid E)=0.15$ & \\
\hline
\end{tabular}

\section{Impetigo}

\begin{tabular}{|c|c|}
\hline \multicolumn{2}{|c|}{ Hitung Nilai Semesta } \\
\hline Gejala & Bobot \\
\hline Bintik bintik bernanah & 1 \\
\hline Bau busuk & 0.8 \\
\hline Lesu & 0.5 \\
\hline Diare & 0.5 \\
\hline Total & 2.8 \\
\hline \multicolumn{2}{|c|}{ Hitung $P(H i)$} \\
\hline Gejala & Nilai Semesta $P(\mathrm{Hi})$ \\
\hline Bintik bintik bernanah & $1 / 2.8=0.36$ \\
\hline Bau busuk & $0.8 / 2.8=0.29$ \\
\hline Lesu & $0.5 / 2.8=0.18$ \\
\hline Diare & $0.5 / 2.8=0.18$ \\
\hline \multicolumn{2}{|c|}{ Probabilitas H Tanpa Memandang Nilai Apapun } \\
\hline Bintik bintik bernanah & $0.36 \times 1=0.36$ \\
\hline Bau busuk & $0.29 \times 0.8=0.23$ \\
\hline Lesu & $0.18 \times 0.5=0.09$ \\
\hline Diare & $0.18 \times 0.5=0.09$ \\
\hline \multicolumn{2}{|c|}{$\sum P(H i) \times P(E \mid H i-n)=0.77$} \\
\hline \multicolumn{2}{|c|}{ Mencari nilai $P(H i \mid E)$} \\
\hline Bintik bintik bernanah & $0 \times 0 / 0.77=0$ \\
\hline Bau busuk & $0.8 \times 0.29 / 0.77=0.30$ \\
\hline Lesu & $0 \times 0 / 0.77=0$ \\
\hline Diare & $0 \times 0 / 0.77=0$ \\
\hline$\sum P(H i \mid E)=0.30$ & \\
\hline
\end{tabular}

\section{Candidiasis}

\begin{tabular}{|c|c|}
\hline \multicolumn{2}{|c|}{ Hitung Nilai Semesta } \\
\hline Gejala & Bobot \\
\hline Bulu rontok & 0.7 \\
\hline Ruam kulit berwarna gelap & 1 \\
\hline Bau busuk & 0.5 \\
\hline Kulit berkerak & 0.7 \\
\hline Total & 2.9 \\
\hline \multicolumn{2}{|c|}{ Hitung $P(H i)$} \\
\hline Gejala & Nilai Semesta $P(H i)$ \\
\hline Bulu rontok & $0.7 / 2.9=0.25$ \\
\hline Ruam kulit berwarna gelap & $1 / 2.9=0.35$ \\
\hline Bau busuk & $0.5 / 2.9=0.18$ \\
\hline Kulit berkerak & $0.7 / 2.9=0.25$ \\
\hline \multicolumn{2}{|c|}{ Probabilitas H Tanpa Memandang Nilai Apapun } \\
\hline Bulu rontok & $0.25 \times 0.7=0.17$ \\
\hline Ruam kulit berwarna gelap & $0.35 \times 1=0.35$ \\
\hline Bau busuk & $0.18 \times 0.5=0.09$ \\
\hline Kulit berkerak & $0.25 \times 0.7=0.17$ \\
\hline \multicolumn{2}{|l|}{$\sum(H i) \times P(E \mid H i-n)=0.77$} \\
\hline \multicolumn{2}{|c|}{ Mencari nilai $P(H i \mid E)$} \\
\hline Bulu rontok & $0.7 \times 0.25 / 0.77=0.22$ \\
\hline Ruam kulit berwarna gelap & $0 \times 0 / 0.77=0$ \\
\hline Bau busuk & $0.5 \times 0.18 / 0.77=0.12$ \\
\hline Kulit berkerak & $0 \times 0 / 0.77=0$ \\
\hline
\end{tabular}

\section{Canine Distemper}

\begin{tabular}{|c|c|}
\hline \multicolumn{2}{|c|}{ Hitung Nilai Semesta } \\
\hline Gejala & Bobot \\
\hline Bulu rontok & 0.5 \\
\hline Kulit berkerak & 0.8 \\
\hline Demam & 0.7 \\
\hline Diare & 0.4 \\
\hline Conjungtiva hiperemi & 0.3 \\
\hline Total & 2.7 \\
\hline \multicolumn{2}{|c|}{ Hitung $P(\boldsymbol{H i})$} \\
\hline Gejala & Nilai Semesta $P(H i)$ \\
\hline Bulu rontok & $0.5 / 2.7=0.19$ \\
\hline Kulit berkerak & $0.8 / 2.7=0.30$ \\
\hline Demam & $0.7 / 2.7=0.26$ \\
\hline Diare & $0.4 / 2.7=0.15$ \\
\hline Conjungtiva hiperemi & $0.3 / 2.7=0.12$ \\
\hline \multicolumn{2}{|c|}{ Probabilitas H Tanpa Memandang Nilai Apapun } \\
\hline Bulu rontok & $0.19 \times 0.5=0.10$ \\
\hline Kulit berkerak & $0.30 \times 0.8=0.24$ \\
\hline Demam & $0.26 \times 0.7=0.19$ \\
\hline Diare & $0.15 \times 0.4=0.06$ \\
\hline Conjungtiva hiperemi & $0.12 \times 0.3=0.04$ \\
\hline \multicolumn{2}{|c|}{$\sum P(H i) \times P(E \mid H i-n)=0.61$} \\
\hline \multicolumn{2}{|c|}{ Mencari nilai $P(H i \mid E)$} \\
\hline Bulu rontok & $0.5 \times 0.19 / 0.61=0.16$ \\
\hline Kulit berkerak & $0 \times 0 / 0.61=0$ \\
\hline Demam & $0 \times 0 / 0.61=0$ \\
\hline Diare & $0 \times 0 / 0.61=0$ \\
\hline Conjungtiva hiperemi & $0 \times 0 / 0.61=0$ \\
\hline
\end{tabular}

\section{Ring Worm}

\begin{tabular}{|c|c|}
\hline \multicolumn{2}{|c|}{ Hitung Nilai Semesta } \\
\hline Gejala & Bobot \\
\hline Bulu rontok & 0.4 \\
\hline
\end{tabular}




\begin{tabular}{|l|c|}
\hline Kaki kapalan & 0.5 \\
\hline Lesi (luka) berbentuk bulat & 1 \\
\hline Bau busuk & 0.7 \\
\hline Sering menjilati lesi (luka) & 0.6 \\
\hline Total & $\mathbf{3 . 2}$ \\
\hline \multicolumn{2}{|c|}{ Hitung $\boldsymbol{P}(\boldsymbol{H i})$} \\
\hline Gejala & Nilai Semesta $\boldsymbol{P}(\boldsymbol{H i})$ \\
\hline Bulu rontok & $0.4 / 32=0.13$ \\
\hline Kaki kapalan & $0.5 / 32=0.16$ \\
\hline Lesi (luka) berbentuk bulat & $1 / 32=0.32$ \\
\hline Bau busuk & $0.7 / 32=0.16$ \\
\hline Sering menjilati lesi (luka) & $0.6 / 32=0.19$ \\
\hline \multicolumn{2}{|c|}{ Probabilitas H Tanpa Memandang Nilai Apapun } \\
\hline
\end{tabular}

\subsection{Hasil Penghitungan}

Hasil perhitungan data sampel pada proses inferensi di atas, dapat dilihat pada Tabel 4.5 berikut.

\begin{tabular}{|l|l|}
\hline Bulu rontok & $0.13 \times 0.4=0.05$ \\
\hline Kaki kapalan & $0.16 \times 0.5=0.08$ \\
\hline Lesi (luka) berbentuk bulat & $0.32 \times 1=0.32$ \\
\hline Bau busuk & $0.22 \times 0.7=0.16$ \\
\hline Sering menjilati lesi (luka) & $0.19 \times 0.6=0.12$ \\
\hline$\sum \boldsymbol{P}(\boldsymbol{H i}) \boldsymbol{x} \boldsymbol{P}(\boldsymbol{E} \mid \boldsymbol{H i}$ - $\boldsymbol{n})=\mathbf{0 . 7 1}$ \\
\hline \multicolumn{2}{|c|}{ Mencari nilai $\boldsymbol{P}(\boldsymbol{H i} \mid \boldsymbol{E})$} \\
\hline Bulu rontok & $0.4 \times 0.13 / 0.71=0.08$ \\
\hline Kaki kapalan & $0.5 \times 0.16 / 0.71=0.12$ \\
\hline Lesi (luka) berbentuk bulat & $1 \times 0.32 / 0.71=0.45$ \\
\hline Bau busuk & $0.7 \times 0.22 / 0.71=0.22$ \\
\hline Sering menjilati lesi (luka) & $0 \times 0 / 0.71=0$ \\
\hline$\sum \boldsymbol{P}(\boldsymbol{H i} \mid \boldsymbol{E})=\mathbf{0 . 8 5}$ & \\
\hline
\end{tabular}

Tabel 4.5 Hasil Perhitungan Data Sampel

\begin{tabular}{|l|l|l|c|c|}
\hline NO & Nama Anjing & \multicolumn{1}{|c|}{ Jenis Penyakit } & Nilai Bayes & Aturan Bayes \\
\hline \multirow{4}{*}{1} & \multirow{4}{*}{ Jodi } & Scabies & 0.49 & Mungkin \\
\cline { 3 - 5 } & & Demodekosis & 0.19 & Tidak Ada \\
\cline { 3 - 5 } & Dermatomicosis & 0.15 & Tidak Ada \\
\cline { 3 - 5 } & Dermatitis & 0.15 & Tidak Ada \\
\cline { 3 - 5 } & Imetigo & 0.34 & Tidak Ada \\
\cline { 3 - 5 } & Candidiasis & 0.16 & Mungkin \\
\cline { 3 - 5 } & Canine Distemper & 0.85 & Tidak Ada \\
\cline { 3 - 5 } & & Ring Worm & Hampir Pasti \\
\hline
\end{tabular}

Berdasarkan hasil perhitungan yang ditunjukan pada Tabel 4.5 di atas bahwa nilai bayes tertinggi adalah 0.85 , yaitu Ring Worm. Selanjutnya dicocokan dengan data aturan bayes bahwa nilai 0.85 adalah "Hampir Pasti". Maka diagnosa untuk anjing dengan nama Jodi adalah Ring Worm.

\subsection{Validasi Hasil}

Validasi hasil yang membandingkan hasil inferensi dari sistem dengan data rekam medis anjing dapat dilihat pada Tabel 4.6 berikut.

Tabel 4.6 Validasi Hasil

\begin{tabular}{|c|l|l|l|l|c|}
\hline \multirow{2}{*}{ NO } & \multirow{2}{*}{ Nama Anjing } & \multicolumn{2}{|c|}{ Nasil Sistem } & \multirow{2}{*}{$\begin{array}{c}\text { Diagnosa } \\
\text { Pakar }\end{array}$} & Validasi \\
\cline { 3 - 5 } & & \multicolumn{1}{|c|}{ Nilai } & \multicolumn{1}{|c|}{ Diagnosa } & Ring Worm & Sesuai \\
\hline 1 & Jodi & 0.89 & Ring Worm & Dermatitis & Sesuai \\
\hline 2 & Pluto & 0.58 & Dermatitis & Demodekosis & Sesuai \\
\hline 3 & Brandy & 1 & Demodekosis & Scabies & Sesuai \\
\hline 4 & Cepi & 0.69 & Scabies & Canine Distemper & Tidak Sesuai \\
\hline 5 & Arshad & 0.90 & Scabies & Impetigo & Sesuai \\
\hline 6 & Brandon & 0.59 & Impetigo & Candidiasis & Sesuai \\
\hline 7 & Hero & 1 & Candidiasis & Dermatomicosis & Sesuai \\
\hline 8 & Yuna & 0.45 & Dermatomicosis & Demodekosis & Sesuai \\
\hline 9 & Bondet & 0.77 & Demodekosis & Candidiasis & Sesuai \\
\hline 10 & Jesica & 0.83 & Candidiasis & Canine Distemper & Sesuai \\
\hline 11 & Piter & 1 & Canine Distemper &
\end{tabular}

Tabel 4.6 di atas menunjukan bahwa berdasarkan 11 data uji rekam medis yang digunakan dalam uji valiadasi tersebut, sistem pakar diagnosa penyakit kulit pada anjing ras dengan metode teorema bayes dapat mendiagnosa 10 data sesuai dengan hasil diagnosa pakar, dan 1 data tidak sesuai. Dengan demikian dapat disimpulkan bahwa sistem pakar diagnosa penyakit kulit pada anjing ras dengan metode teorema bayes ini mampu mendiagnosa penyakit kulit pada anjing ras dengan tingkat akurasi sebesar $91 \%$. 


\section{Kesimpulan}

Dari penelitian yang telah dilakukan kesimpulan yang dapat diambil adalah sebagai berikut;

1. Berdasarkan 11 data rekam medis yang digunakan sebagai data uji pada sistem pakar diagnosa penyakit kulit pada anjing ras dengan metode teorema bayes ini, didapatkan 10 kesesuaian diagnosa dan 1 kasus tidak sesuai dengan diagnosa dokter. Dengan demikian dapat disimpulkan bahwa berdasarkan 11 data uji sampel yang digunakan dalam penelitian ini, sistem pakar diagnosa penyakit kulit pada anjing ras dengan metode teorema bayes ini dapat memberikan hasil diagnosa dengan akurasi sebesar $91 \%$.

2. Sistem yang dirancang dengan metode teorema bayes dapat digunakan untuk membantu dalam mendiagnosa jenis penyakit kulit pada anjing ras.

\section{Daftar Pustaka}

Arhami, M. (2005). Konsep Dasar Sistem Pakar. Yogyakarta: Andi.

Harijanto, B., \& Latif, R. A. (2017). Sistem Pakar Diagnosa Penyakit Pada Kucing Dengan Metode Teorema Bayes Berbasis Android. Informatika Polinema.

Kusumadewi, S. (2003). Artificial Intelligence (Teknik dan Aplikasinya). Yogyakarta: Graha Ilmu.

Larasati, T., \& Arief, R. (2016). Sistem Pakar Diagnosa Awal Penyakit Kulit Kucing
Berbasis WEB Menggunakan Metode Certainly Factor. Sistem Informasi.

Lestari. (2012). Definisi sistem pakar. Arsip Teknik Informatika UMMI.

Ningrum, N. C., Anra, H., \& Nasution, H. (2016). Sistem Pakar Diagnosa Penyakit Menular Pada Anjing Menggunakan Metode Dempster Shafe. Sistem Dan Teknologi Informasi.

Noviyanti, Suheri, C., \& Midyanti, D. M. (2017). Sistem Pakar Untuk Diagnosa Penyakit Rabies Pada Anjing Menggunakan Metode Fuzzy Mamdani Berbasis Web. Jurnal Coding Sistem Komputer.

Rosnelly, R. (2012). Sistem Pakar Konsep Dan Teori. Yogyakarta: Andi.

Rohajawati. (2010). Sistem Pakar Diagnosa Penyakit Unggas Dengan Metode Certainty Factor. Jurnal Sistem Informasi.

Siligipoe, T. (2013). Dog Lover's Book. Jakarta: Gagas Media.

Soeharsono. (2007). Penyakit zZoonotik Pada Anjing Dan Kucing. Yogyakarta: Kanisius.

Subronto. (2006). Penyakit Infeksi Parasit Dan Mikroba Pada Anjing Dan Kucing. Yogyakarta: Gajah Mada University Press.

Turban, E. (1995). Decision Support System and Expert System. Prentice Hall International, New Jersey. 
20 Jurnal Multimedia \& Artificial Intelligence, Volume 2, Nomor 2, Agustus 2018 